\title{
Optimalisasi Pengolah Limbah Organik Penghasil Biogas Skala Rumah Tangga dan Pupuk Organik Cair untuk Meningkatkan Ekonomi Kreatif Kampung Organik Kelompok Wanita Kecamatan Tikala
}

\author{
Susan Marlein Mambu', Glanny Mangindaan ${ }^{2}$, Beivy Kolondam ${ }^{1}$ \\ 1Jurusan Biologi, Fakultas Matematika Dan Ilmu Pengetahuan Alam \\ Universitas Sam Ratulangi ; ${ }^{2}$ Jurusan Elektro, Fakultas Teknik Universitas Sam Ratulangi \\ *Penulis Korespondensi, Susan Marlein Mambu Jurusan Biologi FMIPA Universitas Sam Ratulangi Manado 95115. \\ Email: susan.mambu@unsrat.ac.id
}

\begin{abstract}
ABSTRAK
Berbagai upaya dan strategi terus dilakukan untuk mengintegrasikan gender ke dalam arus pembangunan, antara lain dengan cara menempatkan perempuan sebagai subjek pembangunan dan menghilangkan faktor kendala yang dihadapi perempuan dalam pembangunan. Kegiatan PKM ini melibatkan Mitra kegiatan PKM yang merupakan Kelompok Wanita Organik di Kecamatan Tikala, dengan sebagian besar anggotanya adalah ibu rumah tangga. Meskipun mereka tinggal di ibukota Propinsi Sulawesi Utara, peluang kerja menjadi sangat terbatas, karena keterampilan yang minim. Salah satu ide untuk peningkatan kompetensi dan kesejahteraan ekonomi adalah melalui kegiatan Kampung Organik berupa pemanfaatan dan pengelolaan limbah organik melalui reaktor biogas yang dapat menghasilkan pupuk organik cair dan biogas. Program kemitraan ini bertujuan untuk memanfaatkan limbah organik skala rumah tangga yang mengalami proses pengolahan melalui reaktor biogas untuk menghasilkan pupuk organik cair (POC) yang berguna untuk meningkatkan kandungan bahan organik dan unsur hara dalam tanah, sehingga terjadi perbaikan sifat fisik, kimia dan biologi tanah, yang akhirnya berdampak pada peningkatan produktivitas tanah dan meningkatkan pertumbuhan dan produksi tanaman sebagai peluang bisnis yang bisa menjadi alternatif penghasilan tambahan bagi kelompok Wanita kampung organik serta menghasilkan biogas yang dapat digunakan untuk proses memasak sehari-hari. Metode pelaksanaan kegiatan yaitu metode berbasis kelompok yang dilakukan secara komprehensif meliputi penyuluhan, demonstrasi serta tutorial untuk meningkatkan pengetahuan tentang pembuatan pupuk organik cair yang dihasilkan melalui proses dekomposisi pada reaktor biogas, dan meningkatkan keterampilan bertanam sayuran maupun tanaman hias. Kegiatan tim PKM dilakukan secara terukur disertai proses monitoring evaluasi untuk mengukur ketercapaian target. Hasil kegiatan pengabdian ini menunjukkan terjadinya peningkatan pengetahuan para anggota kelompok wanita organik, yang awalnya sebagian besar kurang mengenal tentang pengolahan limbah organik rumah tangga menjadi pupuk organik cair dan biogas. Terjadi pula peningkatan keterampilan dalam bercocok tanam sayuran dan tanaman hias.
\end{abstract}

Kata kunci:Wanita; Limbah; Pupuk; Organik; Biogas

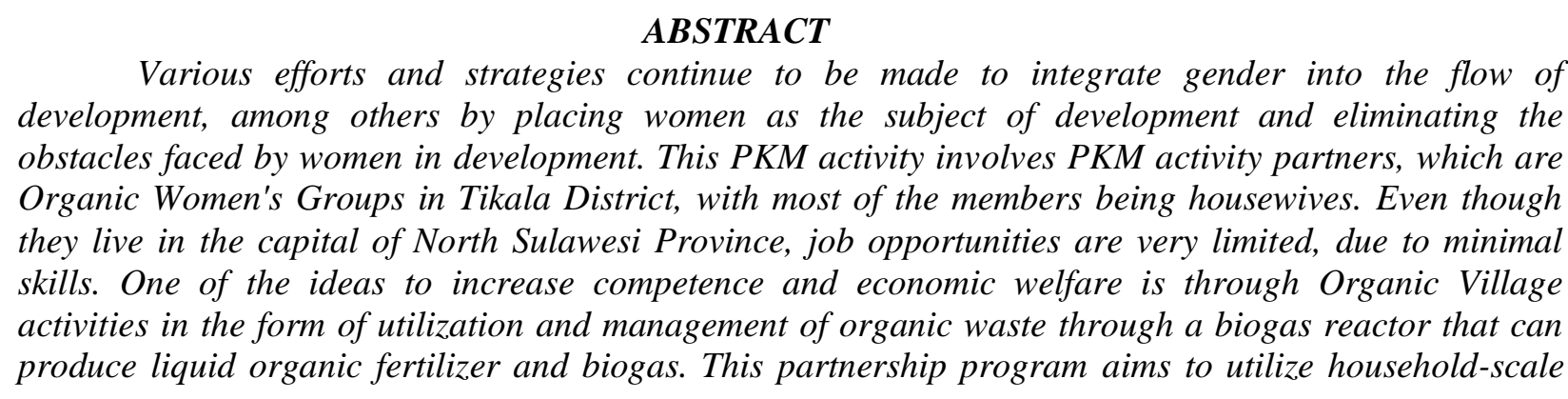


organic waste that undergoes processing through a biogas reactor to produce liquid organic fertilizer (POC) which is useful for increasing the content of organic matter and nutrients in the soil, resulting in improved physical, chemical and biological properties of the soil, which ultimately has an impact on increasing soil productivity and increasing plant growth and production as a business opportunity that can be an alternative additional income for organic village women's groups and produce biogas which can be used for the daily cooking process. The method of implementing the activity is a group-based method that is carried out comprehensively including counseling, demonstrations and tutorials to increase knowledge about the manufacture of liquid organic fertilizer produced through the decomposition process in a biogas reactor, and improve skills in growing vegetables and ornamental plants. The activities of the PKM team are carried out in a measurable manner accompanied by an evaluation monitoring process to measure the achievement of targets. The results of this service activity indicate an increase in the knowledge of members of the organic women's group, which initially mostly did not know about processing household organic waste into liquid organic fertilizer and biogas. There was also an increase in skills in growing vegetables and ornamental plants.

Keywords: Women; Waste; Fertilizer; Organic; Biogas

\section{PENDAHULUAN}

\section{Analisis Situasi}

Peranan kaum Wanita sangat mempengaruhi pembangunan bangsa, sehingga berbagai upaya dan strategi dilakukan untuk menempatkan perempuan sebagai subjek pembangunan dan menghilangkan faktor kendala yang dihadapi perempuan dalam pembangunan. Dreze dan Sen (1995) mengatakan bahwa pada waktu wanita menjadi kaum terdidik, mempunyai hak-hak kepemilikan, dan bebas untuk bekerja di luar rumah serta mempunyai pendapatan mandiri, inilah tanda kesejahteraan rumah tangga meningkat.

Kelompok Wanita di Kecamatan Tikala, merupakan kelompok wanita yang sebagian besar anggotanya adalah ibu rumah tangga, meskipun mereka tinggal di Kota Manado sebagai ibukota Propinsi Sulawesi Utara, peluang kerja menjadi sangat terbatas, karena keterampilan yang minim. Salah satu ide untuk peningkatan kompetensi dan kesejahteraan ekonomi adalah melalui kegiatan Kampung Organik.

Melalui Program Kemitraan Masyarakat atau PKM, Lembaga Penelitian dan Pengabdian Pada Masyarakat Universitas Sam Ratulangi (LPPM UNSRAT) melalui tim penyelenggara PKM telah menjadi salah satu penggagas terbentuknya Kampung Organik ini. Kegiatan penyuluhan dan pelatihan yang telah dilakukan kepada kelompok wanita di Kecamatan Tikala dan beberapa kelompok wanita di kelurahan, telah membuahkan hasil yang cukup baik. Namun, untuk skala yang lebih luas, diperlukan upaya keberlanjutan, terutama pada aspek teknologi.

Usaha sayuran organik dan tanaman hias kembali populer, seiring dengan kegiatan Work From Home dan meningkatnya jumlah PHK para karyawan, yang turut berimbas pada Kelompok Wanita Organik di Kecamatan Tikala. Berbagai upaya terus dilakukan oleh kelompok ini, namun harga pupuk organik dan bibit yang cukup tinggi, serta teknologi pengolahan menjadi kendala bagi usaha ini, padahal ketersediaan lahan cukup memadai.

Produksi sayuran dan tanaman hias akan menghasilkan produk sampingan berupa sisasisa tanaman. Pemanfaatan sisa-sisa tanaman hasil panen belum banyak diperhatikan kegunaannya. Selama ini, sisa tanaman hanya dibuang atau dibakar, padahal pemanfaatan bahan baku lokal sisa tanaman tersebut, akan sangat membantu peningkatan bahan baku tersebut, sehingga secara tidak langsung akan ikut meningkatkan kemajuan perekonomian daerah. Pupuk organik merupakan pupuk yang berasal dari berbagai bahan pembuat pupuk alami seperti kotoran hewan, bagian tubuh hewan, tumbuhan, yang kaya akan mineral serta baik untuk pemanfaatan penyuburan tanah (Leovini, 2012).

Produk teknologi yang akan di desiminasikan adalah reaktor biogas berbentuk kubah, dan sering disebut reaktor Cina, dinamakan demikian karena reaktor ini pertama kali dibuat di Cina pada tahun 1930. Digester ini memiliki dua bagian yaitu digester sebagai tempat penguraian kotoran dan bagian 
penampung gas yang berfungsi untuk menampung limbah sisa panen dan limbah rumah tangga dan tempat berlangsungnya proses dekomposisi dan fermentasi yaitu proses pembentukan gas Metana (Gambar 1), dan memberikan output berupa biogas dan POC (Stohr, 1989).

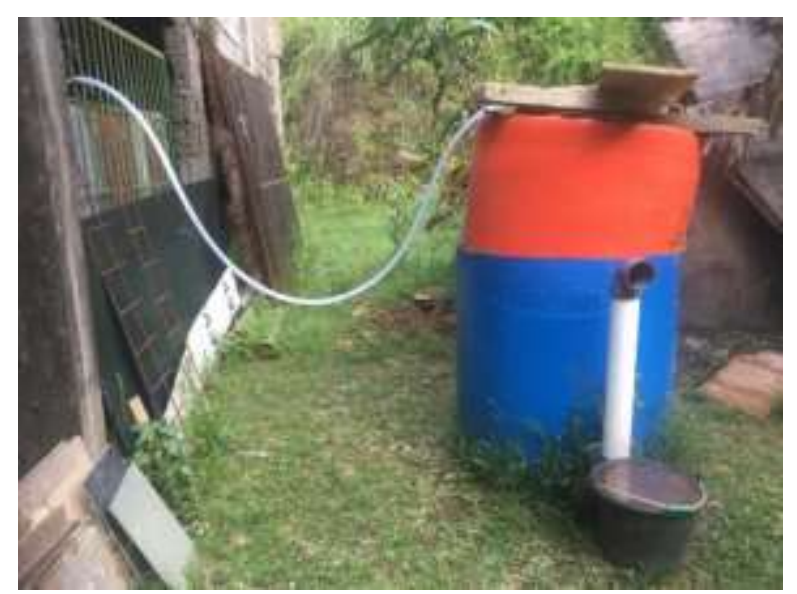

Gambar 1. Reaktor Biogas Skala Rumah Tangga Berbasis Limbah Organik di Kecamatan Tikala

Berdasarkan bentuknya, pupuk organik dibedakan menjadi dua, yaitu cair dan padat (Hadisuwito, 2012). Umumnya kompos padat akan matang dalam waktu kurang lebih 1 bulan, tergantung dari jenis tanaman yang digunakan. Kompos diisi kedalam polybag dan siap ditambahkan dengan tanah, ataupun dibenamkan ke dalam tanah jika akan menanam di lahan (Mambu, et al., 2018).

Kelebihan pupuk cair adalah pada kemampuannya untuk memberikan unsur hara sesuai dengan kebutuhan tanaman, dan dapat mengatasi defisiensi unsur hara dengan lebih cepat, bila dibandingkan dengan pupuk padat. Hal ini didukung oleh bentuknya yang cair sehingga mudah diserap tanah dan tanaman. pupuk ini juga memiliki bahan pengikat sehingga larutan pupuk yang diberikan ke permukaan tanah bisa langsung dimanfaatkan oleh tanaman (Roidah, 2013 ; Febriana et al., 2018).

Berdasarkan uraian solusi terhadap permasalahan mitra, diharapkan melalui transfer ilmu tentang pembuatan POC dan reaktor biogas serta pemanfaatannya bagi usaha sayuran dan tanaman hias kampung organik kelompok wanita di Kecamatan Tikala, dapat meningkatkan kompetensi para wanita dalam meningkatkan ekonomi keluarga, sehingga konsep perempuan khususnya ibu-ibu rumah tangga yang cerdas dan mandiri dari sisi ekonomi dapat terwujud.

\section{Tujuan dan Manfaat Kegiatan}

Sesuai dengan rencana kegiatan, maka luaran yang dihasilkan atau ditargetkan dalam kegiatan pengabdian pada masyarakat ini adalah merakit perangkat teknologi energi terbarukan berupa Reaktor Biogas berskala rumah tangga yang menghasilkan produk berupa biogas yang dapat menjadi energi alternatif pengganti minyak tanah dan juga menghasilkan Pupuk Organik Cair (POC), serta melatih keterampilam kelompok wanita Kecamatan Tikala mengaplikasikan POC pada lahan sayuran dan tanaman hias.

\section{METODE PELAKSANAAN}

\section{Sasaran kegiatan}

Kelompok Wanita Kecamatan Tikala dan Kelompok Wanita Organik Kelurahan Taas sebagai sasaran utama kegiatan ini agar dapat meningkatkan pengetahuan dan keterampilan mereka dan menerapkan hasil pelatihan, sehingga melalui program ini, dapat menambah porsi kepada kaum perempuan untuk lebih eksis meningkatkan peran sertanya dalam pembangunan bangsa.

\section{Lokasi kegiatan}

Kegiatan secara umum dilaksanakan di Kecamatan Tikala, dan Kelurahan Taas, Kota Manado.

\section{Metode yang digunakan :}

Metode pendekatan yang digunakan untuk meyelesaikan permasalahan mitra, terutama untuk mendukung keberhasilan pelaksanaan produk teknologi yang di desiminasikan, sebagai berikut:

1. Metode Penyuluhan/ceramah, berbentuk penyampaian materi oleh Tim sebagai narasumber, dan diskusi bersama anggota kelompok mitra. Materi penyuluhan terdiri dari: a. Materi tentang dampak penggunaan pupuk kimia terhadap kesuburan tanah, air dan lingkungan sekitarnya. 
b. Materi tentang pengenalan pupuk organik cair (POC), keunggulan POC dibandingkan dengan pupuk kimia dari segi ekonomi maupun keberlanjutan lingkungan hidup.

c. Materi yang menjelaskan potensi pemanfaatan sumberdaya hayati lokal dilingkungan sekitar, sebagai bahan baku pembuatan POC.

d. Materi persiapan lahan, penyemaian benih, penanaman sayur, pemeliharaan (pengendalian hama dan penyakit terpadu), panen dan pasca panen.

e. Materi tentang apa yang dimaksud dengan reaktor biogas, kegunaannya, cara merakit sampai menghasilkan biogas sebagai bahan bakar alternatif pengganti gas atau minyak tanah (gambar 1).

f. Materi cara-cara pembuatan POC menggunakan reaktor biogas dan proses dekomposisi limbah serta produk yang dihasilkan (Gambar 2).

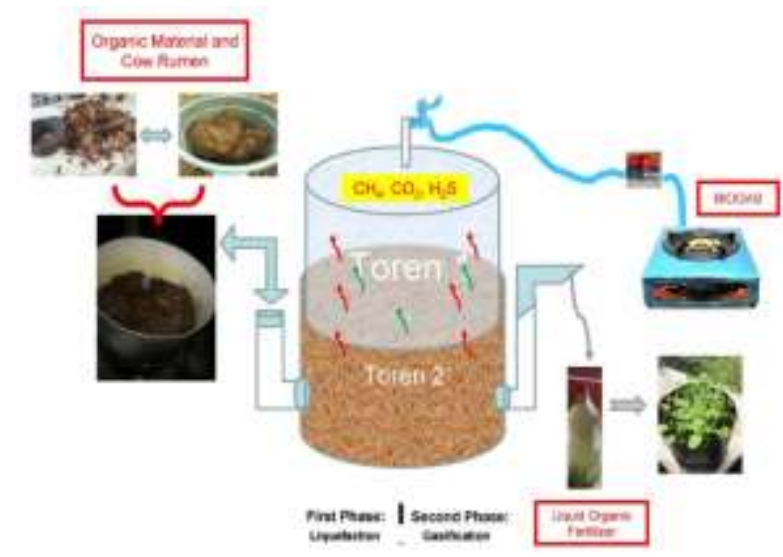

Gambar 2. Proses Input dan Output pada Reaktor Biogas

2. Metode pelatihan, tutorial, demonstrasi dan praktek lapangan bersama mitra, sesuai dengan materi penyuluhan. Materi pelatihan sebagai berikut:

a. Praktek persiapan, pengolahan lahan, semai benih, pindah tanam dan penanaman di lahan.

b. Praktek penggunaan bagan daun untuk mengetahui kebutuhan pupuk susulan.

c. Melatih cara pemupukan, pengendalian gulma dan pengolahan hama terpadu.

d. Melatih cara panen terutama kriteria tanaman siap panen.

e. Melatih cara membuat POC.

f. Merakit bahan-bahan pembuat reaktor biogas.
3. Pembuatan percontohan teknologi yang akan di desiminasikan kepada mitra, yaitu:

a. Pembangunan rumah POC terpadu sekaligus sebagai tempat tray penyemaian bibit.

b. Pembuatan lahan siap tanam untuk 2 jenis sayur dan 2 jenis tanaman hias yang sudah dipersiapkan selama pelatihan.

c. Perakitan reaktor biogas dan rumah POC terpadu yang telah dirancang dan dibangun selama pelatihan.

d. Penyediaan limbah sisa tanaman sebagai produk pembuatan POC yang akan dimasukkan ke dalam reaktor biogas untuk mengalami proses dekomposisi.

e. Uji coba reaktor biogas untuk memastikan jumlah hari sampai menghasilkan POC dan biogas yang akan dialirkan ke kompor gas unuk dipakai sebagai kebutuhan masak sehari-hari.

\section{HASIL DAN PEMBAHASAN}

Produk kegiatan yang dihasilkan dalam kegiatan ini selain berupa produk teknologi, tapi juga berupa perubahan paradigma (pola pikir) dan peningkatan pengetahuan serta keterampilan mitra tentang rancang bangun reaktor biogas, potensi pemanfaatan sumberdaya hayati lokal dilingkungan sekitar, sebagai bahan baku pembuatan POC, dan persiapan, pengolahan lahan, semai benih, pindah tanam dan penanaman di lahan. Perubahan atau peningkatan pengetahuan mitra tentang hal-hal tersebut, dapat diukur dari perbandingan antara nilai tes sebelum kegiatan berlangsung (pretest) dengan nilai test setelah kegiatan berlangsung (posttest).

\section{A. Pelaksanaan tes awal (pretest)}

Sebelum pelaksanaan kegiatan, dilakukan pretest yang bertujuan untuk mengukur pengetahuan mitra tentang reaktor biogas, kegunaannya, cara merakit sampai menghasilkan biogas, serta pengetahuan tentang POC, keunggulan POC dibandingkan dengan pupuk kimia. Pretest berbentuk pilihan berganda dengan jumlah soal sebanyak 10 soal. Waktu yang diberikan selama 15 menit. Jumlah peserta yang mengikuti pretest sebanyak 12 orang. Materi pretest meliputi pengertian reaktor biogas, bahaya/efek samping pestisida terhadap lingkungan, manusia, dan mikroba tanah, serta mekanisme pembentukan biogas dan POC. 
Hasil pretest menunjukkan bahwa rata-rata pengetahuan mitra tentang reaktor biogas dan POC masih rendah, karena sebagian besar mitra memiliki pemahaman $(99,98 \%)$ mendapat nilai kecil dari 50. Peserta yang mendapat nilai tertinggi pada interval 21-30 dan 31-40 berjumlah masing-masing 3 orang $(25,0 \%)$, dan terendah pada 3 interval lainnya sejumlah masing-masing 3 orang. (Tabel 1). Berdasarkan hasil pretest ini perlu diberikan pengetahuan tentang apa itu reaktor biogas dan produk yang dihasilkan.

\section{B. Pelaksanaan posttest (tes akhir)}

Kegiatan ini dilaksanakan untuk melihat sejauh mana keberhasilan dari kegiatan yang telah dilaksanakan. Jumlah soal dalam tes ini sama dengan tes awal sebanyak 10 soal dalam bentuk pilihan berganda. Waktu yang diberikan selama 15 menit. Peserta yang mengikuti tes ini sebanyak 12 peserta. Materi test mencakup materi yang disampaikan dalam proses penyuluhan. Hasil menunjukkan adanya peningkatan nilai tes akhir dibandingkan dengan test awal (Tabel 1). Hal ini menunjukkan terjadinya peningkatan pemahaman dan pengetahuan peserta terhadap proses perakitan reaktor biogas, output berupa POC serta kegunaannya.

Perbandingan nilai pretest dan posttest juga disajikan pada Gambar 3 yang menunjukkan terjadinya peningkatan pemahaman pengetahuan mitra tentang reaktor biogas, kegunaannya, serta pengetahuan tentang POC, keunggulan POC yang ditandai dengan tidak terdapat peserta yang memiliki nilai di bawah 50 pada nilai posttest $(0,00 \%)$, dibandingkan dengan nilai pretest, atau terjadi peningkatan nilai pada interval (51100). Hal ini menunjukkan bahwa kegiatan penyuluhan dan kerja lapangan yang diberikan benar-benar dapat meningkatkan pengetahuan dan pemahaman mitra.
Tabel 1. Nilai Pretest Dan Posttest Peserta Penyuluhan/Pelatihan Reaktor Biogas dan POC

\begin{tabular}{|c|c|c|c|c|c|}
\hline \multirow{2}{*}{ No } & \multirow{2}{*}{ Interval } & \multicolumn{2}{|c|}{ Pretest } & \multicolumn{2}{|c|}{ Posttest } \\
\hline & & Jml & $\%$ & Jml & $\%$ \\
\hline 1 & $0-10$ & 2 & 16,66 & 0 & 0,00 \\
\hline 2 & $11-20$ & 2 & 16,66 & 0 & 0,00 \\
\hline 3 & $21-30$ & 3 & 25,0 & 0 & 0,00 \\
\hline 4 & $31-40$ & 3 & 25,0 & 0 & 0,00 \\
\hline 5 & $41-50$ & 2 & 16,66 & 0 & 0,00 \\
\hline 6 & $51-60$ & 0 & 00,00 & 1 & 8,33 \\
\hline 7 & $61-70$ & 0 & 0,00 & 1 & 8,33 \\
\hline 8 & $71-80$ & 0 & 0,00 & 2 & 16,66 \\
\hline 9 & $81-90$ & 0 & 0,00 & 5 & 41,66 \\
\hline 10 & $91-100$ & 0 & 0,00 & 3 & 25,00 \\
\hline \multicolumn{2}{|c|}{ Jumlah } & 12 & 100,00 & 12 & 100,00 \\
\hline
\end{tabular}

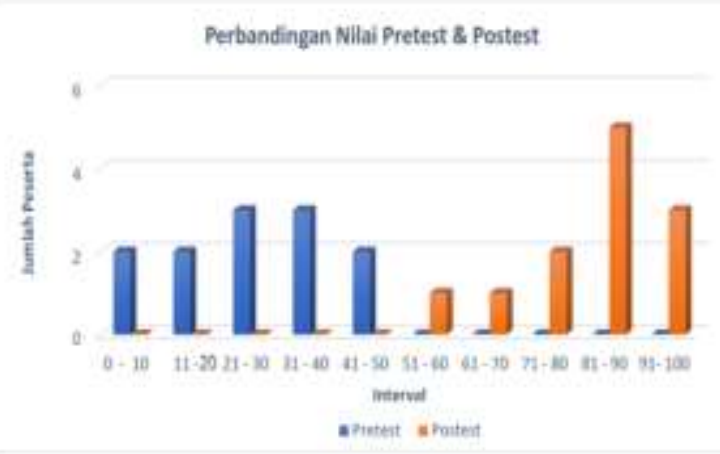

Gambar 3. Perbandingan Nilai Pretest Dan Posttest Peserta Penyuluhan/Pelatihan Reaktor Biogas dan POC

\section{KESIMPULAN DAN SARAN}

Kegiatan PKM ini dapat terlaksana dengan baik, walaupun harus menyesuaikan dengan keadaan yang disebabkan oleh pandemi Covid-19. Beberapa indikator pencapaian tujuan Program Kemitraan Masyarakat ini dapat tercapai, sehingga bukan hanya menghasilkan produk teknologi, tapi juga berupa perubahan paradigma (pola pikir) dan peningkatan pengetahuan serta keterampilan mitra tentang rancang bangun dan mengelola reaktor biogas, 
potensi pemanfaatan sumberdaya hayati lokal dilingkungan sekitar sebagai bahan baku pembuatan POC, dan persiapan, pengolahan lahan, semai benih, pindah tanam dan penanaman di lahan.

Mengingat pentingnya kegiatan ini, diperlukan metode berbasis kelompok dengan jumlah anggota yang lebih kecil, perlu dilakukan penyuluhan dan monitoring secara berkala

\section{UCAPAN TERIMAKASIH}

Terima Kasih disampaikan kepada Kementerian Pendidikan, Kebudayaan, Riset dan Teknologi, Deputi Bidang Penguatan Riset dan Pengembangan Kementerian Riset dan Teknologi/ Badan Riset dan Inovasi Nasional yang telah membiayai pelaksanaan kegiatan PKM ini. Ucapan terima kasih juga disampaikan kepada LPPM UNSRAT dan Tim BioTeknologi PKM yang telah bekerjasama selama pelaksanaan kegiatan. Ucapan terima kasih juga disampaikan kepada PKK Kecamatan Tikala, dan Kelompok Wanita Organik yang telah berpartisipasi sebagai mitra pelaksana kegiatan pengabdian ini, dan kepada semua pihak yang tidak dapat disebutkan satu-persatu.

\section{DAFTAR PUSTAKA}

\section{Buku}

Dreze, Jean dan Sen, Amartya. 1999. The Amartya Sen and Jean Drèze Omnibus:(comprising) Poverty and Famines; Hunger and Public Action; India: Economic Development and Social Opportunity. Oxford University Press.

Hadisuwito, S. (2012). Membuat Pupuk Kompos Cair. Jakarta: PT. Agromedia Pustaka.

\section{Jurnal}

Febrianna, M., Prijono, S., Kusumarini, N. (2018). Pemanfaatan Pupuk Organik Cair untuk Meningkatkan Serapan Nitrogen serta Pertumbuhan dan Produksi Sawi (Brassica juncea L.) pada Tanah Berpasir. Jurnal Tanah dan Sumberdaya Lahan, 5 (2): 10091018.

Leovini, H. (2012). Pemanfaatan Pupuk Organik Cair Pada Budidaya Tanaman Tomat (Solanum lycopersicum L.). Jurusan
Budidaya Pertanian, Fakultas Pertanian Universitas Gadjah Mada.

Mambu, S., Sugihara, S., Kawame, T., Nishigaki, T., Toyota, K., Miyamaru, N., Tanaka, H., dan Kanekatsu, M. 2018. Effect of Green Manure Application on Soil Enzyme Activity and Nutrient Dynamics in a Sugarcane Field of Kitadaito, Okinawa, Japan, JARQ, 54(4):315-324

Stohr, U.W., 1989. Biogas Plants in Animal Husbandry A Practical Guide. (Informatica International, Inc.). 